\title{
Pengaruh kurs, inflasi, PDB dan harga karet internasional terhadap ekspor karet Indonesia Ke Tiongkok dan Amerika Serikat
}

\author{
Faisal Fihri* ; Haryadi ; Nurhayani \\ Prodi Ekonomi Pembangunan Fak.Ekonomi dan Binsis Universitas Jambi \\ *E-mail korespondensi : fihrifaisall @gmail.com
}

\begin{abstract}
This study aims to: 1) calculate and analyze the development of exchange rates, inflation, GDP, international rubber prices, and Indonesian rubber exports to China and the United States. 2) To determine the income contribution of women workers in Talang Village, 3). To calculate and analyze the factors that affect the export of Indonesian rubber to China and the United States. The analytical method used is descriptive quantitative using multiple linear regression analysis. The results show that the exchange rate development fluctuated from 2001 to 2019, with an average exchange rate development from 2001 to 2019 of 3.13 percent. Then the average general annual inflation of Indonesia for 19 years with inflation developments that occur up and down or fluctuate. The average growth of rubber prices is 9.24 percent. Furthermore, the volume of rubber exports to China in 2001-2019 tends to decrease. The average development of rubber export volume to China in 2001-2019 was 1.95 percent. Meanwhile, the development of rubber export volume to America in 2001-2019 tends to increase. The average growth of rubber export volume to China in 2001-2019 was 1.34 percent. Based on the results of multiple linear regression, the importance of rubber exports to China is influenced by the variables of the exchange rate, GDP, and rubber prices. Meanwhile, the rubber price variable only affects the volume of rubber exports to America.
\end{abstract}

Keywords: Export of rubber, Exchange rate, Inflation, GDP, Rubber price

\begin{abstract}
Abstrak
Penelitian ini bertujuan untuk: 1) Untuk menghitung dan menganalisis perkembangan kurs, inflasi, PDB, Harga Karet internasional dan ekspor Karet Indonesia ke Tiongkok dan Amerika Serikat. 2) Untuk mengetahui kontribusi pendapatan perempuan pekerja di Kelurahan Talang, 3).Untuk menghitung dan menganalisis faktor-faktor yang mempengaruhi ekspor Karet Indonesia ke Tiongkok Amerika Serikat. Metode analisis yang digunakan yaitu deskripstif kuantitatif dengan menggunakan alat analisis regresi linier berganda. Hasil menunjukkan perkembangan kurs mengalami fluktuasi selama tahun 2001 sampai tahun 2019 dengan rata-rata perkembangan kurs selama tahun 2001 sampai tahun 2019 yaitu 3,13 persen. Kemudian rata-rata inflasi,tahunan umum Indonesia selama 19 tahun dengan perkembangan inflasi yang terjadi secara naik turun atau berfluktuasi. Rata-rata perkembangan harga karet sebesar 9,24 persen. Selanjutnya perkembangan volume ekspor karet ke Tiongkok tahun 2001-2019 lebih cenderung mengalami penurunan. Rata-rata perkembangan volume ekspor karet ke Tiongkok tahun 2001-2019 sebesar -1,95 persen. Sedangkan perkembangan volume ekspor karet ke Amerika tahun 2001-2019 lebih cenderung mengalami peningkatan. Rata-rata perkembangan volume ekspor karet ke Tiongkok tahun 2001-2019 sebesar 1,34 persen. Berdasarkan hasil regresi linear ganda bahwa volume ekspor karet ke Tiongkok dipengaruhi oleh variabel kurs, PDB dan harga karet. Sedangkan volume ekspor karet ke Amerika hanya dipengaruhi oleh variabel harga karet.
\end{abstract}

Kata kunci: Ekspor karet, Kurs, Inflasi, PDB, Harga karet 


\section{PENDAHULUAN}

Indonesia merupakan suatu Negara berkembang Menganut sistem ekonomi terbuka dan lalu lintas perekonomian internasional sangat penting di dalam perekonomian dan pembangunan nasional. Pembangunan ekonomi masyarakat dilakukan dengan cara meningkatkan kesejahteraan masyarakat, dan salah satu ukuran dari peningkatan kesejahteraan tersebut adalah adanya pertumbuhan ekonomi (BPS Indonesia, 2019).

Hubungan antara ekspor dan pertumbuhan ekonomi sangat tidak bisa dipisahkan dalam waktu belakangan ini sudah menjadi perhatian berbagai kalangan. Perdagangan Internasional khususnya ekspor yang diyakinkan sebagai penggerak utama dalam pertumbuhan ekonomi dan peningkatan cadangan devisa (Nopirin, 2017). Ekspor merupakan agregat output yang sangat dominan dalam perdagangan internasional. Suatu Negara jika tidak ada ikatan atau kerjasama dengan negara lain maka akan sulit untuk memenuhi kebutuhannya (Mankiw, 2018).

Perdagangan internasional dapat terjadi apabila negara yang melakukan perdagangan memperoleh manfaat dari perdagangan dan memberikan peluang pada setiap negara yang memiliki sumber daya melimpah untuk melakukan ekspor barang atau jasa, serta memberikan peluang melakukan impor bagi negara yang memiliki biaya produksi relatif mahal untuk melakukan produksi di dalam negeri. Perdagangan internasional dapat menjadi roda penggerak perekonomian suatu negara jika dilakukan secara efisien dan efektif, serta mengetahui peluang - peluang yang dimiliki suatu negara (Tambunan, 2004).

Indonesia sebagai salah satu negara yang menganut sistem perekonomian terbuka, sangat mengandalkan kegiatan perdagangan internasional untuk membantu meningkatkan pertumbuhan ekonomi. Perdagangan internasional memungkinkan suatu negara untuk mempelajari teknik produksi dan cara - cara memimpin perusahaan lebih modern. Yang lebih terpenting lagi, perdagangan internasional memingkinkan negara tersebut mengimpor teknik produksi dan cara produksi yang lebih baik. Keuntungan ini terutama akan dinikmati olehnegara-negara berkembang, karena negara-negara berkembang umumnya masih banyak yang menggunakan teknik produksi dengan cara yang relatif sederhana (Haryadi 2015).

Penyebab Utama perdagangan internasional adalah untuk memperoleh manfaat yang ditimbulkan oleh spesialisasi antar negara. walaupun suatu negara dapat memproduksi barang-barang dan jasa yang sama jenisnya dengan barang dan jasa yang dihasilkan oleh negara lain, tetapi mungkin negara tersebut lebih suka mengimpir barang-barang tadi dari luar negeri dan bukannya menghasilkan barang dan jasa tersebut di dalam negeri (Boediono, 2018).

Sebagai gantinya negara tersebut dapat memperluas kegiatannya dalam menghasilkan barang-barang yang dapat dijual dan dapat menguntungkan di luar negeri. Dengan cara ini, negara-negara dapat menggunakan faktor produksi secara efisien, selain itu negara tersebut akan dapat menikmati barang lebih banyak ketimbang negara tersebut tidak melakukan spesialisasi dalam perdagangan (Haryadi 2015).

Indonesia merupakan salah satu negara pemasok ekspor migas dan nonmigas di pasar dunia. Tidak kurang dari 140 negara yang menjadi tujuan ekspor Indonesia. Dari data statistik yang dikeluarkan oleh Biro Pusat Statistik (BPS), hampir 5.000 macam produk dari Indonesia masuk ke pasar negaranegara tersebut (Kementerian Perdagangan). Dalam transaksi perdagangan internasional hal yang paling penting adalah sisi impor dan ekspor. Salah satunya adalah ekspor. Indonesia merupakan daerah subtropis yang potensial untuk 
pengembangan komoditas primer perkebunan.

Salah satu komoditas primer perkebunan utama Indonesia yaitu karet. Karet merupakan salah satu komoditas ekspor andalan pekebunan yang mempunyai peran sebagai penghasil devisa, karet merupakan komoditias global bernilai ekonomi tinggi. Perkembangan volume ekspor komoditas primer perkebunan berupa Karet Pada tahun 2010 produksi karet alam Indonesia adalah sebesar 2.736.000 ton dan merupakan produsen karet terbesar setelah Thailand yang memproduksi karet alam sebanyak 3.252.100 ton.

Tingginya kapasitas produksi karet alam di Indonesia disebabkan oleh lahan yang digunakan untuk tanaman karet cukup luas, selain itu iklim tropis yang ada di Indonesia sesuai dengan penanaman pohon karet. Dibandingkan dengan produksi komoditas unggulan lainnya seperti kopi, teh, dan coklat produksi karet alam Indonesia sangat besar. Negara tujuan ekspor karet alam Indonesia terbesar untuk eropa adalah Tiongkok. Indonesia sebagai salah satu negara pengekspor karet terbesar ke Tiongkok memiliki kesempatan untuk mendapatkan keuntungan dari kegiatan ekspor tersebut yaitu untuk meningkatkan cadangan devisa, namun terjadi penurunan ekspor karet alam Indonesia ke Tiongkok selama satu dekade. Penurunan ekspor ini berbanding terbalik dengan GDP Tiongkok yang setiap tahunnya mengalami peningkatan.

Tanaman karet adalah tanaman tahunan yang dapat tumbuh sampai umur 30 tahun. Habitus tanaman ini merupakan pohon dengan tinggi tanaman dapat mencapai $15-20$ meter. Modal utama dalam pengusahaan tanaman ini adalah batang setinggi 2,5 sampai 3 meter dimana terdapat pembuluh latek. Oleh karena itu fokus pengelolaan tanaman karet ini adalah bagaimana mengelola batang tanaman ini seefisien mungkin. Deskripsi untuk pengenalan tumbuhan karet (Hevea brasiliensis Muell. Arg.). Tanaman karet memiliki sifat gugur daun sebagai respon tanaman terhadap kondisi lingkungan yang kurang menguntungkan (kekurangan air/kemarau).

Pada saat ini sebaiknya penggunaan stimulan dihindarkan. Daun ini akan tumbuh kembali pada awal musim hujan. Tanaman karet juga memiliki sistem perakaran yang ekstensif/menyebar cukup luas sehingga tanaman karet dapat tumbuh pada kondisi lahan yang kurang menguntungkan.

Akar ini juga digunakan untuk menyeleksi klonklon yang dapat digunakan sebagai batang bawah pada perbanyakan tanaman karet. Tanaman karet memiliki masa belum menghasilkan selama lima tahun (masa TBM 5 tahun) dan sudah mulai dapat disadap pada awal tahun ke enam. Secara ekonomis tanaman karet dapat disadap selama 15 sampai 20 tahun.

Produksi karet alam yang tinggi diikuti dengan besarnya nilai ekspor karet alam Indonesia. Nilai Ekspor karet alam Indonesia juga cenderung mengalami peningkatan, penurunan nilai ekspor yang terjadi pada tahun 2009 merupakan akibat turunnya harga dari karet alam di pasar internasional yang disebabkan oleh krisis keuangan global. Negara tujuan ekspor karet alam Indonesia terbesar untuk wilayah asia adalah Tiongkok. Indonesia sebagai salah satu negara pengekspor karet terbesar ke Tiongkok memiliki kesempatan untuk mendapatkan keuntungan dari kegiatan ekspor tersebut yaitu untuk meningkatkan cadangan devisa, namun terjadi tren penurunan ekspor karet alam Indonesia ke Tiongkok selama satu dekade.

Penurunan ekspor ini berbanding terbalik dengan GDP Tiongkok yang setiap tahunnya mengalami peningkatan. Tren penurunan ekspor karet alam yang terjadi selama satu dekade telah berdampak pada pemasukan cadangan devisa Indonesia. Ada beberapa faktor yang mempengaruhi ekspor karet alam Indonesia ke Tiongkok baik dalam jangka 
pendek maupun dalam jangka panjang. Selain diakibatkan karena adanya perubahan GDP Tiongkok, produksi karet alam dalam negeri dan harga karet alam Indonesia juga merupakan indikator perubahan ekspor karet alam Indonesia. Tanaman perkebunan merupakan pendukung utama sektor pertanian dalam menghasilkam devisa. Ekspor komoditi pertanian Indonesia yang utama adalah hasil-hasil perkebunan. Hasil-hasil perkebunan yang selama ini telah menjadi komoditi ekspor konvensional terdiri atas karet, kelapa sawit, kakao, teh, kopi, lada dan tembakau. Karet merupakan salah satu komuditi perkebunan yang sangat penting peranannya dalam perekonomia Indonesia.

Pada tahun 2019 produksi karet alam Indonesia sebesar 3.449.272 ton. Tingginya kapasitas produksi karet alam di Indonesia disebabkan oleh lahan yang digunakan untuk tanaman karet cukup luas, selain itu iklim yang tropis yang ada di Indonesia sesuai dengan penanaman pohon karet. Dibandingkan dengan produk komoditas unggulan lainnya seperti kopi, teh, dan kakao, produksi karet Indonesia sangat tinggi. Karet alam Indonesia pada tahun 2015-2019 menempati kedudukan tertinggi dibandingkan dengan kopi, teh, dan kakao. Pada tahun 2015 produksi karet alam cukup tinggi sebesar 3.145.184 ton, dan pada tahun 2016 produksi karet alam mengalami peningkatan sebesar 3.307.254. Kemudian terjadi peningkatan lagi di tahun 2017 menjadi 3.680.402 ton. Pada tahun 2018 produksi karet masih mengalami peningkatan yaitu menjadi sebesar 3.630.197 ton sementara pada tahun 2019 mengalami penurunan menjadi 3.449.218 ton, penurunan ini sangat erat kaitannya dengan menurunnya permintaan karet. Sedangkan perkembangan produksi perkebunan Indonesia yang menempati tempat terendah yaitu teh. Sejumlah lokasi di Indonesia memiliki keadaan lahan yang cocok untuk pertanaman karet, sebagian besar di wilayah Sumatra Selatan, Sumatera Utara, Riau, Jambi, Kalimantan Barat, Kalimantan Tengah, dan sebagainya. Berikut kami lampirkan jumlah ekspor dari indonesia ke negara Tiongkok.

Tabel 1. Data tabel volume ekspor karet, kurs, inflasi, pdb dan harga karet Internasional ke Negara Tiongkok

\begin{tabular}{cccccc}
\hline Tahun & $\begin{array}{c}\text { Volume Ekspor } \\
\text { Karet (Ton) }\end{array}$ & $\begin{array}{c}\text { Kurs } \\
\text { (Ribu } \\
\text { Rupiah) }\end{array}$ & $\begin{array}{c}\text { Inflasi } \\
(\boldsymbol{\%})\end{array}$ & $\begin{array}{c}\text { PDB } \\
\text { (Milyar Rupiah) }\end{array}$ & $\begin{array}{c}\text { Harga Karet } \\
\text { Internasional } \\
\text { (USD/Ton) }\end{array}$ \\
\hline 2015 & 421,7 & 13.436 & 3,35 & 3.051 .149 & 1.306 \\
2016 & 425,0 & 13.548 & 3,13 & 3.204 .317 & 1.280 \\
2017 & 425,9 & 13.795 & 3,02 & 3.366 .776 & 1.080 \\
2018 & 433,7 & 14.031 & 2,78 & 3.540 .838 & 760 \\
2019 & 500,9 & 14.409 & 2,72 & 3.714 .900 & 580 \\
\hline
\end{tabular}

Sumber : BPS Indonesia, 2021

Dalam kurun waktu 5 tahun terakhir, ekspor karet Indonesia ke Tiongkok mengalami peningkatan, Pada Tahun 2016 Ekspor karet indonesia ke Tiongkok adalah sebesar 425 ribu ton dari data ekspor ini indonesia mengalami peningkatan ekspor karet dari tahun sebelumnya yang berjumlah 421,7 ribu ton ton pada tahun 2015, pada tahun 2017 ekspor karet indonesia mengalami peningkatan pada tahun ini yaitu sebesar 425,9 ribu ton. Kemudian tahun 2018 volum ekspor karet mengalami peningkatan menjadi 433,7 ribu ton hingga tahun 2019 menjadi 500,9 ribu ton.

Tabel 2. Data tabel volume ekspor karet, kurs, inflasi, PDB dan harga karet Internasional ke Negara Amerika Serikat 


\begin{tabular}{cccccc}
\hline Tahun & $\begin{array}{c}\text { Volume Ekspor } \\
\text { Karet (Ton) }\end{array}$ & $\begin{array}{c}\text { Kurs } \\
\text { (Ribu } \\
\text { Rupiah) }\end{array}$ & $\begin{array}{c}\text { Inflasi } \\
(\boldsymbol{\%})\end{array}$ & $\begin{array}{c}\text { PDB } \\
\text { (Milyar Rupiah) }\end{array}$ & $\begin{array}{c}\text { Harga Karet } \\
\text { Internasional } \\
\text { (USD/Ton) }\end{array}$ \\
\hline 2015 & 594,8 & 13.436 & 3,35 & 3.051 .149 & 1.306 \\
2016 & 595,4 & 13.548 & 3,13 & 3.204 .317 & 1.280 \\
2017 & 601,5 & 13.795 & 3,02 & 3.366 .776 & 1.080 \\
2018 & 609 & 14.031 & 2,78 & 3.540 .838 & 760 \\
2019 & 633,5 & 14.409 & 2,72 & 3.714 .900 & 580 \\
\hline
\end{tabular}

Sumber : BPS Indonesia, 2021

Dalam kurun waktu 5 tahun terakhir, ekspor karet Indonesia ke Amerika Serikat mengalami peningkatan, sama seperti eskpor karet Indonesia ke negara Tiongkok yang mengalami peningkatan dari tahun 2015 sampai dengan 2019. Dari data perbandingan yang telah dijelaskan pada Tabel 1.1 dan Tabel 1.2 dapat dijelaskan bahwa Nilai Ekspor Indonesia ke Amerika Serikat merupakan nilai ekspor tertinggi dibandingkan dengan nilai ekspor Indonesia ke Tiongkok. Namun tetap mengalami fluktuasi nilai ekspor karet pada kurun waktu 5 (lima) tahun terakhir,

Kurs adalah harga sebuah mata uang dari sutu negara yang diukur atau dinyatakan dalam mata uang lainnya. Kurs memainkan peranan penting dalam keputusan-keputusan pembelanjaan, Karena kurs memungkinkan kita menerjemahkan harga-harga dari berbagai negara ke dalam satu bahasa yang sama. Bila semua kondisi lainnya tetap, depresiasi mata uang dari suatu negara terhadap segenap mata uang lainnya (kenaikan harga valuta asing bagi negara yang bersangkutan) menyebabkan ekspornya lebih murah dan impornya lebih mahal. Sedangkan apresiasi (penurunan harga valuta asing di negara yang bersangkutan) membuat ekspornya lebih mahal dan impornya lebih murah Berikut kami lampirkan data nilai tukar indonesia terhadap dolar beberapa tahun terakhir.

Untuk nilai tukar dapat dijelaskan bahwa nilai tukar rupiah terhadap Dollar Amerika Selama 5 tahun terakhir mengalami fluktuasi dari tahun ke tahun, pada tahun 2015 kurs dollar amerika sebesar Rp. 13.795 per dollar. Pada tahun 2016 kurs rupiah menguat mencapai angka Rp. 13.436 per dollar Amerika dan pada tahun 2017 Kurs Rupiah melemah dengan nilai Rp. 13.548 per Dollar Amerika. Pada tahun 2018 kurs rupiah melemah mencapai angka Rp. 14.409 per dollar Amerika dan pada tahun 2017 Kurs Rupiah kembali menguat dengan nilai Rp. 14.031 per Dollar Amerika.

Inflasi adalah suatu keadaan perekonomian dimana harga-harga secara umum megalami kenaikan dalam waktu yang panjang. Kenaikan harga yang bersifat sementara seperti kenaikan harga pada masa lebaran tidak dianggap sebagai inflasi, karena disaat setelah masa lebaran, harga-harga dapat turun kembali. Inflasi secara umum dapat terjadi karena jumlah uang beredar lebih banyak dari pada yang dibutuhkan. Inflasi merupakan suatu gejala ekonomi yang tidak pernah dapat dihilangkan dengan tuntas. Usaha usaha yang dilakukan biasanya hanya sampai batas mengurangi dan mengendalikan. Inflasi Indonesia Sendiri dari 5 tahun terakhir mengalami fluktuasi, pada tahun 2015 inflasi indonesia adalah 3,510\% kemudian pada tahun 2016 inflasi indonesia terus mengalami penurunan dan mencapai angka 3,02\%, pada tahun 2017 inflasi indonesia mengalami peningkatan sebesar $3,61 \%$, pada tahun 2018 menurun menjadi 3,13\% dan tahun 2019 juga menurun menjadi 2,72 persen.

Pendapatan Domestik Bruto (PDB) adalah nilai seluruh barang-barang dan jasa-jasa yang dihasilkan oleh sesuatu perekonomian dalam suatu periode tertentu. Produk Nasional Bruto (GNP) adalah pendapatan nasional yang dihitung dengan mengeluarkan faktor 
pendapatan dari warga negara asing yang berdomisili di negara tersebut dan hanya menghitung nilai barang dan jasa yang dihasilkan oleh orang yang bekewarganegaraan negara tersebut saja. PDB Indoensia selama 5 tahun terakhir juga mengalami perkembangan yang terus meningkat. PDB Indonesia tahun 2015 sebesar Rp. 11.529.332 milyar terus meningkat menjadi Rp. 10.772.442 milyar.

Harga adalah nilai tukar yang bisa disamakan dengan uang atau barang lain untuk manfaat yang diperoleh dari suatu barang atau jasa bagi seseorang atau kelompok pada waktu tertentu dan tempat tertentu. Harga penawaran adalah harga yang bersedia dibayar oleh pialang atau pelaku pasar atas suatu produk sekuritas, seperti saham atau obligasi, pada waktu tertentu.

Berdasarkan latar belakang masalah tersebut maka penulis tertarik mengambil judul "pengaruh kurs, inflasi, PDB dan harga karet internasional terhadap ekspor karet Indonesia Ke Tiongkok dan Amerika Serikat".

\section{METODE}

\section{Analisis kuantitatif}

Untuk menjawab rumusan masalah yang kedua menggunakan rumus regresi linier berganda.

$$
\mathbf{Y}=\boldsymbol{\beta}+\mathbf{P}_{1} \mathbf{X}_{1}+\mathbf{P}_{2} \mathbf{X}_{2}+\epsilon_{\mathbf{x}}
$$

Dimana :

Y : Variabel tidak bebas

$\mathrm{X}_{1}, \mathrm{X}_{2}$ : Variabel bebas

$\in \quad$ : Variabel lain yang berpengaruh namun tidak masuk dalam penelitian

Untuk menganalisis pengaruh variabel independen $(\mathrm{X})$ terhadap variabel dependen (Y) adalah sebagai berikut:

Dimana :

$$
\text { EKit }=\beta 0+\text { NTit }+ \text { INFit }+ \text { PDBit }+ \text { HKit }+\mathbf{e}_{x}
$$

EK $_{\text {it }}$ : Volume ekspor karet tahun $\mathrm{t}$

$\beta_{0} \quad$ : Konstanta

$\mathrm{NT}_{\text {it }}$ : Nilai kurs pada tahun $\mathrm{t}$

$\mathrm{INF}_{\text {it }}$ : Inflasi Indonesia pada tahun $\mathrm{t}$

PDBit : Pendapatan domestik bruto pada tahun $\mathrm{t}$

$\mathrm{HK}_{\mathrm{it}}$ : Harga karet pada tahun $\mathrm{t}$

$\mathrm{e}_{\mathrm{x}} \quad$ : Variabel lain yang tidak dimasukkan dalam penelitian ini

\section{Uji statistik}

Proses analisa yang akan dilakukan melalui pengujian variabelvariabel independen yang meliputi uji F (uji bersamasama), uji t (uji individual), dan uji $\mathrm{R}^{2}$ (uji koefisien determinasi).

\section{Uji F}

Uji F ini merupakan pengujian bersama-sama variabel independen yang dilakukan untuk melihat pengaruh variabel independen secara bersama-sama terhadap variabel dependen secara signifikan. Langkahlangkah pengujian adalah sebagai berikut (Gujarati, 2015) : 
Nilai F hitung $=\frac{\frac{R^{2}}{n}(K-1)}{\left(1-R^{2}\right)(N-K}$

$\mathrm{R}^{2}:$ Koefisien determinasi

$\mathrm{N}$ : jumlah observasi/ sample

$\mathrm{K}$ : banyaknya variabel.

Apabila nilai F hit < F table, maka Hipotesis diterima dan Hipotesis ditolak, artinya variabel independen secara bersama-sama tidak berpengaruh terhadap variabel dependen secara signifikan. Apabila nilai F hit > F tamble, maka Hipotesis ditolak dan Hipotesis diterima, artinya variabel independen secara bersama-sama berpengaruh terhadap variabel dependen secara signifikan

\section{Uji t}

Uji t ini merupakan pengujian variabel-variabel secara individu, dilakukan untuk mengetahui seberapa jauh pengaruh masing-masing variabel independen dalam mempengaruhi variabel dependen, dengan beranggapan variabel independen lain tetap / konstan. Langkah-langkah pengujian t test adalah sebagai berikut (Gujarati, 2015).

Melakukan perhitungan nilai t sebagai berikut:

Nilai $t$ table $=t_{\alpha / 2} ; \mathbf{N}-K$

Keterangan:

$\alpha=$ Derajat signifikansi

$\mathrm{N}=$ Jumlah sample (banyaknya observasi)

$\mathrm{K}=$ Banyaknya parameter

Nilai t hit $=\frac{\beta i}{S e(\beta i}$

Keterangan:

$\beta_{\mathrm{i}} \quad=$ Koefisien regresi

$\operatorname{Se}\left(\beta_{\mathrm{i}}\right)=$ Standar error koefisien regresi iii. Kriteria pengujian

Apabila nilai $-\mathrm{t}$ table $<\mathrm{t}$ hit $<\mathrm{t}$ table, Artinya variabel Independen tidak berpengaruh terhadap variabel dependen secara signifikan. Kemudian, apabia nilai $t$ hit $>+t$ table atau $t$ hit $<$-t table, Artinya variabel independen mampu mempengaruhi variabel dependen secara signifikan.

\section{Uji $\mathbf{R}^{\mathbf{2}}$ (uji koefisien determinasi)}

Nilai $\mathrm{R}^{2}$ untuk mengetahui berapa persen variasi variabel dependen dapat dijelaskan oleh variabel independen. Uji ini bertujuan untuk mengetahui tingkat ketepatan yang paling baik dalam analisis regresi, yang ditunjukkan oleh besarnya koefisien determinasi $\left(\mathrm{R}^{2}\right)$ antara nol dan satu $\left(0<\mathrm{R}^{2}<1\right)$. Jika koefisien determinasi 0 , artinya variabel independen tidak mempengaruhi variabel dependen, atau dengan kata lain model tersebut tidak menjelaskan sedikitpun variasi dalam variabel tidak bebas. Sedangkan koefisien determinan mendekati 1, artinya variabel independen semakin mepengaruhi variabel dependen, atau dengan kata lain model dikatakan lebih baik apabila koefisien determinasinya mendekati 1 . 


\section{HASIL DAN PEMBAHASAN}

\section{Uji simultan}

Untuk menguji pengaruh antara variabel bebas (variabel independen) terhadap variabel terikat (variabel dependent) secara simultan digunakan alat uji $\mathrm{F}$ statistik yang dapat dilihat pada hasil output program SPSS 20 pada tabel ANNOVA sebagai berikut:

Tabel 3. Hasil uji F statistik

\begin{tabular}{llrrrrr}
\hline & Model & Sum of Squares & df & Mean Square & \multicolumn{1}{l}{ F } & \multicolumn{1}{c}{ Sig. } \\
\hline 1 & Regression & 52878,950 & 4 & 13219,738 & 61,557 &, $000^{\mathrm{b}}$ \\
& Residual & 3006,588 & 14 & 214,756 & & \\
Total & 55885,538 & 18 & & & \\
\hline
\end{tabular}

a. Dependent Variable: EK

b. Predictors: (Constant), HK, NT, PDB, INF

Sumber : Data diolah, 2021

Berdasarkan hasil regresi diketahui atau diperoleh signifikansi F-sig sebesar 0,000 lebih kecil dari 0,1 . Artinya Ho ditolak dan Ha diterima, hal ini dapat diartikan bahwa variabel bebas (Kurs, Inflasi, PDB dan Harga Karet Internasional) secara bersama-sama (simultan) berpengaruh signifikan terhadap variabel terikat (ekspor karet Indonesia ke Tiongkok) selama periode 2001-2019.

\section{Uji parsial}

Uji statistik merupakan pengujian secara parsial yang bertujuan untuk mengetahui apakah masing-masing koefisien regresi signifikan atau tidak terhadap variabel dependent dengan menganggap variabel lainnya konstan. Untuk melihat hasil setiap variabel terikat secara parsial yang diuji dengan uji-t secara rinci koefisien regresi pada setiap variabel dapat dilihat pada Tabel 4 yang menunjukkan hasil sebagai berikut :

Tabel 4. Hasil regresi linier berganda

\begin{tabular}{|c|c|c|c|c|c|c|c|}
\hline \multirow{2}{*}{ Model } & \multicolumn{2}{|c|}{$\begin{array}{l}\text { Unstandardized } \\
\text { Coefficients }\end{array}$} & \multirow{2}{*}{$\begin{array}{c}\text { Standardized } \\
\text { Coefficients } \\
\text { Beta } \\
\end{array}$} & \multirow[t]{2}{*}{$\mathbf{t}$} & \multirow{2}{*}{ Sig. } & \multicolumn{2}{|c|}{ Collinearity Statistics } \\
\hline & $\mathbf{B}$ & Std. Error & & & & Tolerance & VIF \\
\hline (Constant & 738,434 & 36,472 & & 20,247 & 000 & & \\
\hline NT & 012 & ,006 & ,460 & 1,945 & 072 &, 169 & 4,530 \\
\hline INF & $-3,606$ & 5,281 &,- 252 &,- 683 &, 506 &, 128 & 5,514 \\
\hline PDB & $6,718 \mathrm{E}-5$ &, 000 &, 876 & 2,848 & 013 &, 141 & 4,624 \\
\hline HK &,- 059 &, 019 & $-1,118$ & $-3,059$ & ,009 &, 129 & 4,769 \\
\hline
\end{tabular}

a. Dependent Variable: EK

Sumber : Data diolah, 2021

\section{Variabel kurs}

Dari hasil pengujian diperoleh nilai probabilita untuk variabel kurs sebesar 0,072. dengan tingkat keyakinan $(\alpha=10 \%)$, dari perhitungan tersebut dapat dilihat bahwa nilai 
probabilita lebih kecil dari alpha $(0,072<0,1)$, artinya Ho ditolak dan Ha diterima artinya kurs berpengaruh signifikan terhadap Ekspor Karet Indonesia Ke Tiongkok.

\section{Variabel Inflasi}

Dari hasil pengujian diperoleh nilai probabilita untuk variabel nilai tukar sebesar 0,506. dengan tingkat keyakinan $(\alpha=10 \%)$, dari perhitungan tersebut dapat dilihat bahwa nilai probabilita lebih besar dari alpha $(0,506>0,1)$, artinya Ho diterima dan Ha ditolak artinya inflasi tidak berpengaruh signifikan terhadap Ekspor Karet Indonesia Ke Tiongkok.

\section{Variabel PDB}

Dari hasil pengujian diperoleh nilai probabilita untuk variabel PDB sebesar 0,013. dengan tingkat keyakinan $(\alpha=10 \%)$, dari perhitungan tersebut dapat dilihat bahwa nilai probabilita lebih kecil dari alpha $(0,013<0,1)$, artinya Ho ditolak dan Ha diterima artinya PDB berpengaruh signifikan terhadap Ekspor Karet Indonesia Ke Tiongkok.

\section{Variabel harga karet}

Dari hasil pengujian diperoleh nilai probabilita untuk variabel harga karet sebesar 0,009 . dengan tingkat keyakinan $(\alpha=10 \%)$, dari perhitungan tersebut dapat dilihat bahwa nilai probabilita lebih kecil dari alpha $(0,009<0,1)$, artinya Ho ditolak dan Ha diterima artinya harga karet berpengaruh signifikan terhadap Ekspor Karet Indonesia Ke Tiongkok.

\section{Koefisien determinasi}

Analisis koefisiensi determinasi digunakan untuk melihat beberapa besar variabel bebas berpengaruh terhadap variabel terikat yang dinyatakan dalam persentase. Seperti yang ditunjukkan pada tabel berikut :

Tabel 5. Hasil uji $\mathrm{R}^{2}$ square

\begin{tabular}{|c|c|c|c|c|}
\hline Model & $\mathbf{R}$ & R Square & $\begin{array}{l}\text { Adjusted R } \\
\text { Square }\end{array}$ & $\begin{array}{c}\text { Std. Error of the } \\
\text { Estimate }\end{array}$ \\
\hline 1 &, $973^{\mathrm{a}}$ & ,946 & ,931 & 14,65456 \\
\hline
\end{tabular}

Sumber : Data diolah, 2021

Tabel 5 dapat dilihat model summary diketahui nilai Adjusted $\mathrm{R}_{\text {square }}$ sebesar 0,931. Artinya sebesar 93,1 persen variasi Ekspor Karet Indonesia Ke Tiongkok dijelaskan oleh variabel bebas dalam model, sedangkan sisanya 6,9 persen dijelaskan oleh variabel lain diluar penelitian.

\section{Analisis ekonomi}

\section{Pengaruh kurs terhadap ekspor karet Indonesia ke Tiongkok}

Berdasarkan hasil regresi diketahui bahwa kurs berpengaruh signifikan terhadap ekspor karet Indonesia ke Tiongkok, dengan nilai koefisien sebesar 0,012, hal ini berarti setiap terjadi peningkatan kurs Rp. 1 maka rata-rata ekspor karet Indonesia ke Tiongkok meningkat sebesar 0,012 Ton dengan asumsi variabel bebas lainnya dalam keadaaan relatif atau tidak berubah. Hasil ini sependapat dengan teori yang dikatakan oleh Boediono (2018) yang mengatakan secara makro dapat dikatakan bahwa kegiatan ekspor akan menjadi lebih menarik dan menguntungkan bagi perekonomian karena akan menambah jumlah transaksi 
ekonomi di dalam negeri dan menambah minat dunia usaha untuk meningkatkan ekspor ke luar negeri. Jadi dapat disimpulkan bahwa melemahnya nilai tukar rupiah atau meningkatnya kurs dollar dapat meningkatkan ekspor dan perekonomian dalam negeri. Namun sebaliknya, jika nilai tukar rupiah menguat atau kurs dolar melemah maka akan menurunkan ekspor dan perekonomian dalam negeri.

\section{Pengaruh inflasi terhadap ekspor karet Indonesia ke Tiongkok}

Berdasarkan hasil regresi diketahui bahwa inflasi tidak berpengaruh signifikan terhadap ekspor karet Indonesia ke Tiongkok, dengan nilai koefisien sebesar -3,606, hal ini berarti setiap terjadi peningkatan inflasi sebessar 1 persen maka rata-rata ekspor karet Indonesia ke Tiongkok menurun sebesar 3,606 Ton dengan asumsi variabel bebas lainnya dalam keadaaan relatif atau tidak berubah. Hasil ini tidak sependapat dengan penelitian yang dilakukan oleh Novianti dan Hapsari (2014) yang mengatakan bahwa infalsi berpnegaruh signifikan terhadap ekspor. Tidak berpengaruhnya inflasi terhadap ekspor karet Indonesia ke Tiongkok karena inflasi di Inonesia tidak berada pada kategori inflasi ringan sehingga tidak menjadi faktor penentu ekspor karet ke Tiongkok.

\section{Pengaruh PDB Jepang terhadap ekspor karet Indonesia ke Tiongkok}

Berdasarkan hasil regresi diketahui bahwa PDB berpengaruh signifikan terhadap ekspor karet Indonesia ke Tiongkok, dengan nilai koefisien sebesar 0,00006718, hal ini berarti setiap terjadi peningkatan PDB sebesar 1 milyar maka rata-rata ekspor karet Indonesia ke Tiongkok meningkat sebesar 0,00006718 Ton dengan asumsi variabel bebas lainnya dalam keadaaan relatif atau tidak berubah. Hasil ini sependapat dengan penelitian yang dilakukan oleh Novianti dan Hapsari (2014) yang mengatakan bahwa PDB berpengaruh signifikan terhadap ekspor. Berpengaruhnya PDB terhadap ekspor karet Indonesia ke Tiongkok karena meningkatnya produksi karet dalam negeri yang meningkat maka akan mendorong peningkatan ekspor.

\section{Pengaruh harga karet terhadap ekspor karet Indonesia ke Tiongkok}

Berdasarkan hasil regresi diketahui bahwa harga karet berpengaruh signifikan terhadap ekspor karet Indonesia ke Tiongkok, dengan bilai koefisien harga karet sebesar 0,059, hal ini berarti setiap terjadi peningkatan harga karet sebesar US\$ 1 maka rata-rata ekspor karet Indonesia ke Tiongkok menurun sebesar 0,059 Ton dengan asumsi variabel bebas lainnya dalam keadaaan relatif atau tidak berubah. Hasil ini sependapat dengan teori yang dikemukakan Sukirno (2016) Penetapan harga suatu produk atau jasa tergantung dari tujuan perusahaan atau penjual yang memasarkan produk tersebut. Dengan tingginya volume harga yang diperoleh maka semakin tinggi jumlah yang akan diekspor. Hal ini dapat dipastikan bahwa pengaruh harga terhadap ekspor adalah positif dan tingginya jumlah harga ekspor akan menyebabkan jumlah produk yang diekspor .

\section{Pengaruh kurs, inflasi, PDB dan harga karet internasional terhadap ekspor karet Indonesia Ke Amerika}

Untuk menguji pengaruh antara variabel bebas (variabel independen) terhadap variabel terikat (variabel dependent) secara simultan digunakan alat uji $\mathrm{F}$ statistik yang dapat dilihat pada hasil output program SPSS 20 pada tabel ANNOVA sebagai berikut: 
Tabel 6. Hasil uji F statistik

\begin{tabular}{llrrrrr}
\hline & Model & \multicolumn{1}{c}{$\begin{array}{c}\text { Sum of } \\
\text { Squares }\end{array}$} & df & Mean Square & \multicolumn{1}{c}{ F } & \multicolumn{1}{c}{ Sig. } \\
\hline 1 & Regression & 91382,194 & 4 & 22845,549 & 74,500 &, $000^{\mathrm{b}}$ \\
& Residual & 4293,137 & 14 & 306,653 & & \\
& Total & 95675,332 & 18 & & & \\
\hline
\end{tabular}

a. Dependent Variable: EK

b. Predictors: (Constant), HK, NT, PDB, INF

Sumber : Data diolah, 2021

Berdasarkan hasil regresi diketahui atau diperoleh signifikansi F-sig sebesar 0,000 lebih kecil dari 0,1. Artinya Ho ditolak dan Ha diterima, hal ini dapat diartikan bahwa variabel bebas (Kurs, Inflasi, PDB dan Harga Karet Internasional) secara bersama-sama (simultan) berpengaruh signifikan terhadap variabel terikat (Ekspor Karet Indonesia Ke Amerika) selama periode 2001-2019.

\section{Uji parsial}

Uji statistik merupakan pengujian secara parsial yang bertujuan untuk mengetahui apakah masing-masing koefisien regresi signifikan atau tidak terhadap variabel dependent dengan menganggap variabel lainnya konstan. Untuk melihat hasil setiap variabel terikat secara parsial yang diuji dengan uji-t secara rinci koefisien regresi pada setiap variabel dapat dilihat pada Tabel 7 yang menunjukkan hasil sebagai berikut :

Tabel 7. Hasil regresi linier berganda

\begin{tabular}{|c|c|c|c|c|c|c|c|}
\hline \multirow{2}{*}{ Model } & \multicolumn{2}{|c|}{$\begin{array}{c}\text { Unstandardized } \\
\text { Coefficients }\end{array}$} & \multirow{2}{*}{$\begin{array}{c}\begin{array}{c}\text { Standardized } \\
\text { Coefficients }\end{array} \\
\text { Beta }\end{array}$} & \multirow{2}{*}{$\mathbf{t}$} & \multirow{2}{*}{ Sig. } & \multicolumn{2}{|c|}{ Collinearity Statistics } \\
\hline & B & $\begin{array}{c}\text { Std. } \\
\text { Error }\end{array}$ & & & & Tolerance & VIF \\
\hline (Constant) & 522,291 & 43,582 & & 11,984 & ,000 & & \\
\hline NT &,- 011 & 007 &,- 325 & $-1,506$ & 154 & 169 & 4,530 \\
\hline INF & 1,651 & 6,310 & ,088 & ,262 & ,797 & 128 & 5,514 \\
\hline PDB & $3,970 \mathrm{E}-5$ &, 000 & 396 & 1,408 &, 181 &, 141 & 4,624 \\
\hline HK &,- 066 &, 023 &,- 960 & $-2,877$ & 012 & 129 & 4,769 \\
\hline
\end{tabular}

Sumber: Data diolah, 2021

\section{Variabel kurs}

Dari hasil pengujian diperoleh nilai probabilita untuk variabel kurs sebesar 0,154. dengan tingkat keyakinan $(\alpha=10 \%)$, dari perhitungan tersebut dapat dilihat bahwa nilai probabilita lebih besar dari alpha $(0,154>0,1)$, artinya Ho diterima dan Ha ditolak artinya kurs tidak berpengaruh signifikan terhadap Ekspor Karet Indonesia Ke Amerika.

\section{Variabel inflasi}

Dari hasil pengujian diperoleh nilai probabilita untuk variabel nilai tukar sebesar 0,797. dengan tingkat keyakinan $(\alpha=10 \%)$, dari perhitungan tersebut dapat dilihat bahwa nilai probabilita lebih besar dari alpha $(0,797>0,1)$, artinya Ho diterima dan Ha ditolak artinya inflasi tidak berpengaruh signifikan terhadap Ekspor Karet Indonesia Ke Amerika.

\section{Variabel PDB}

Dari hasil pengujian diperoleh nilai probabilita untuk variabel PDB sebesar 0,181. dengan tingkat keyakinan $(\alpha=10 \%)$, dari perhitungan tersebut dapat dilihat bahwa nilai 
probabilita lebih kecil dari alpha $(0,181>0,1)$, artinya Ho diterima dan Ha ditolak artinya PDB tidak berpengaruh signifikan terhadap Ekspor Karet Indonesia Ke Amerika.

\section{Variabel harga karet}

Dari hasil pengujian diperoleh nilai probabilita untuk variabel harga karet sebesar 0,012. dengan tingkat keyakinan $(\alpha=10 \%)$, dari perhitungan tersebut dapat dilihat bahwa nilai probabilita lebih kecil dari alpha $(0,012<0,1)$, artinya Ho ditolak dan Ha diterima artinya harga karet berpengaruh signifikan terhadap Ekspor Karet Indonesia Ke Amerika.

\section{Koefisien determinasi}

Analisis koefisiensi determinasi digunakan untuk melihat beberapa besar variabel bebas berpengaruh terhadap variabel terikat yang dinyatakan dalam persentase. Seperti yang ditunjukkan pada tabel berikut :

Tabel 8 Hasil uji $\mathrm{R}^{2}$ square

\begin{tabular}{lrrrr}
\hline Model & R & R Square & $\begin{array}{c}\text { Adjusted R } \\
\text { Square }\end{array}$ & $\begin{array}{c}\text { Std. Error of the } \\
\text { Estimate }\end{array}$ \\
\hline 1 &, $977^{\mathrm{a}}$ &, 955 &, 942 & 17,51150 \\
\hline
\end{tabular}

Sumber: Data diolah, 2021

Tabel 8 diatas dapat dilihat model summary diketahui nilai Adjusted $\mathrm{R}_{\text {square }}$ sebesar 0,955. Artinya sebesar 95,5 persen variasi Ekspor Karet Indonesia Ke Amerika dijelaskan oleh variabel bebas dalam model, sedangkan sisanya 4,5 persen dijelaskan oleh variabel lain diluar penelitian.

\section{Analisis ekonomi}

\section{Pengaruh kurs terhadap ekspor karet Indonesia ke Amerika}

Berdasarkan hasil regresi diketahui bahwa kurs tidak berpengaruh signifikan terhadap ekspor karet Indonesia ke Amerika, dengan nilai koefisien sebesar 0,011, hal ini berarti setiap terjadi peningkatan kurs Rp. 1 maka rata-rata ekspor karet Indonesia ke Amerika menurun sebesar 0,012 Ton dengan asumsi variabel bebas lainnya dalam keadaaan relatif atau tidak berubah. Hasil ini tidak sependapat dengan teori yang dikatakan oleh Boediono (2018) yang mengatakan secara makro dapat dikatakan bahwa kegiatan ekspor akan menjadi lebih menarik dan menguntungkan bagi perekonomian karena akan menambah jumlah transaksi ekonomi di dalam negeri dan menambah minat dunia usaha untuk meningkatkan ekspor ke luar negeri. Jadi dapat disimpulkan bahwa melemahnya nilai tukar rupiah atau meningkatnya kurs dollar dapat meningkatkan ekspor dan perekonomian dalam negeri. Namun sebaliknya, jika nilai tukar rupiah menguat atau kurs dolar melemah maka akan menurunkan ekspor dan perekonomian dalam negeri. Berpengaruhnya harga secara negatif terhadap nilai kurs karena harga sangat menentukan keputusan untuk mengkurs.

\section{Pengaruh inflasi terhadap ekspor karet Indonesia ke Amerika}

Berdasarkan hasil regresi diketahui bahwa inflasi tidak berpengaruh signifikan terhadap ekspor karet Indonesia ke Amerika, dengan nilai koefisien sebesar 1,651, hal ini berarti setiap terjadi peningkatan inflasi sebessar 1 persen maka rata-rata ekspor karet Indonesia ke Amerika meningkat sebesar 1,651 Ton dengan asumsi variabel bebas lainnya dalam keadaaan relatif atau tidak berubah. Hasil ini tidak sependapat dengan penelitian yang 
dilakukan oleh Novianti dan Hapsari (2014) yang mengatakan bahwa infalsi berpnegaruh signifikan terhadap ekspor. Tidak berpengaruhnya inflasi terhadap ekspor karet Indonesia ke Amerika karena inflasi di Inonesia tidak berada pada kategori inflasi ringan sehingga tidak menjadi faktor penentu ekspor karet ke Amerika.

\section{Pengaruh PDB Jepang terhadap ekspor karet Indonesia ke Amerika}

Berdasarkan hasil regresi diketahui bahwa PDB tidak berpengaruh signifikan terhadap ekspor karet Indonesia ke Amerika, dengan nilai koefisien sebesar 0,00003970, hal ini berarti setiap terjadi peningkatan PDB sebesar 1 milyar maka rata-rata ekspor karet Indonesia ke Amerika meningkat sebesar 0,00003970 Ton dengan asumsi variabel bebas lainnya dalam keadaaan relatif atau tidak berubah. Hasil ini tidak sependapat dengan penelitian yang dilakukan oleh Novianti dan Hapsari (2014) yang mengatakan bahwa PDB berpengaruh signifikan terhadap ekspor. Berpengaruhnya PDB terhadap ekspor karet Indonesia ke Amerika karena meningkatnya produksi karet dalam negeri yang meningkat maka akan mendorong peningkatan ekspor.

\section{Pengaruh harga karet terhadap ekspor karet Indonesia ke Amerika}

Berdasarkan hasil regresi diketahui bahwa harga karet berpengaruh signifikan terhadap ekspor karet Indonesia ke Amerika, dengan bilai koefisien harga karet sebesar 0,066, hal ini berarti setiap terjadi peningkatan harga karet sebesar US\$ 1 maka rata-rata ekspor karet Indonesia ke Amerika menurun sebesar 0,066 Ton dengan asumsi variabel bebas lainnya dalam keadaaan relatif atau tidak berubah. Hasil ini sependapat dengan teori yang dikemukakan Sukirno (2016) Penetapan harga suatu produk atau jasa tergantung dari tujuan perusahaan atau penjual yang memasarkan produk tersebut. Dengan tingginya volume harga yang diperoleh maka semakin tinggi jumlah yang akan diekspor. Hal ini dapat dipastikan bahwa pengaruh harga terhadap ekspor adalah positif dan tingginya jumlah harga ekspor akan menyebabkan jumlah produk yang diekspor.

\section{KESIMPULAN DAN SARAN}

\section{Kesimpulan}

Perkembangan kurs mengalami fluktuasi selama tahun 2001 sampai tahun 2019. Ratarata perkembangan kurs selama tahun 2001 sampai tahun 2019 yaitu 3,13 persen. Kemudian rata-rata inflasi,tahunan umum Indonesia selama 19 tahun adalah 6,51 persen per tahun mengacu periode 2001-2019 dimana perkembangan inflasi terjadi secara naik turun atau berfluktuasi. Selanjutnya perkembangan PDB atau disebut pertumbuhan ekonomi Indonesia selama tahun 2001 sampai tahun 2019 cenderung berfluktuasi. Pada tahun 2001 hingga tahun 2019, perkembangan PDB sangat tidak stabil (Badan Pusat Statistik). Kemudian dapat dilihat bahwa selama tahun 2001 sampai tahun 2019 perkembangan harga karet cenderung mengalami penurunan yang ditunjukkan dengan perkembangan harga karet di Indonesia dari tahun 2011 hingga tahun 2018 yang cenderung mengalami penurunan. Rata-rata perkembangan harga karet sebesar 9,24 persen. Selanjutnya perkembangan volume ekspor karet ke Tiongkok tahun 2001-2019 lebih cenderung mengalami penurunan. Rata-rata perkembangan volume ekspor karet ke Tiongkok tahun 2001-2019 sebesar -1,95 persen. Sedangkan perkembangan volume ekspor karet ke Amerika tahun 2001-2019 lebih cenderung mengalami peningkatan. Rata-rata perkembangan volume ekspor karet ke Tiongkok tahun 2001-2019 sebesar 1,34 persen. 
Berdasarkan hasil regresi linear ganda bahwa volume ekspor karet ke Tiongkok dipengaruhi oleh variabel kurs, PDB dan harga karet. Sedangkan volume ekspor karet ke Amerika hanya dipengaruhi oleh variabel harga karet

\section{Saran}

Pemerintah, penguasaha dan semua pihak yang terkait diharapkan dapat meningkatkan produksi karet di Indonesia, karena dengan memperbanyak produksi karet dengan jumlah besar, maka akan dapat menaikkan angka nilai ekspor karet Indonesia dan dapat menambah angka pendapatan nasional. Untuk pengambil kebijakan ekspor karet ke Tiongkok bahwa kurs, PDB dan harga karet internasional dapat menjadi penentu kuota ekspor karet ke Tiongkok. Sedangkan kebijakan ekspor karet ke Tiongkok bahwa hanya harga karet internasional dapat menjadi penentu kuota ekspor karet ke Amerika.

\section{DAFTAR PUSTAKA}

Badan Pusat Statistik. (2019). Statistik Indonesia 2018. BPS: Jakarta.

Boediono. (2018). Ekonomi Internasional, BPFE: Yogyakarta

C Mustika, A Amril. (2015).Analisis pengaruh ekspor ke jepang terhadap pertumbuhan ekonomi dan jumlah pengangguran di Indonesia Periode 1993 sampai 2013, Jurnal Paradigma Ekonomika, 10 (1).

D Hastuti, A Delis, R Rosmeli. (2018).Pengembangan komoditas kelapa sawit dan karet serta dampaknya terhadap pendapatan petani di Kecamatan Pelepat Ilir, Jurnal Sains Sosio Humaniora 2 (2), 92-104

D Hastuti, ME Purnawan, S Sunargo. (2019). Pengaruh variabel-variabel di sektor riil dan perbankan terhadap Shock Credit Default Swap (CDS) di Indonesia, e-Journal Perdagangan Industri dan Moneter, 7 (3), 185-204

Griffin, R. W., \& Pustay, M. W. (2015). Bisnis Internasional sebuah perspektif manajerial. Salemba Empat: Jakarta.

Gujarati, D. N., \& Porter, D. C. (2015). Dasar-dasar Ekonometrika. Salemba Empat: Jakarta.

Halim, Muh Abdul. (2018). Terori ekonomi mikro. Mitra Wacana Media: Jakarta.

Hamdani dan Haikal.(2017). Seluk beluk perdagangan ekspor impor Jilid 1. Bushindo: Jakarta.

Haryadi. (2015). Ekonomi internasional teori dan aplikasi, Biografika: Bogor.

Ida Ayu Diah Fitri, Ida Bagus Pt Purbadharmaja (2015). Pengaruh kurs dollar Amerika, jumlah produksi dan luas lahan pada volume ekspor lada Indonesia. E-Jurnal Ekonomi Pembangunan Universitas Udayana, 4(5), 375-389

Mankiw N. Gregory, (2018). Pengantar ekonomi makro edisi 7, Salemba Empat: Jakarta.

Novianti dan Hapsari, (2014). Faktor - faktor yang mempengaruhi eskspor karet sintetis ke Negara Cina. Universitas Islam Indonesia, Fakultas Ekonomi Yogyakarta: Yogyakarta

Rahma Nurjanah dan Erni Achmad. (2018). Dampak input (tenaga kerja) dan output (GDP) sektor pertanian terhadap konsumsi pemerintah di Indonesia. Jurnal Paradigma Ekonomika, 13(1), 1-6. https://doi.org/10.22437/paradigma.v13i1.4900

Sukirno, Sadono. (2016). Makro ekonomi teori pengantar edisi ketiga. Rajawali Pers: Jakarta.

Todaro, Michael P. and Smith, Stephen C. (2015). Economic Development, Twelfth Edition. Pearson Addison Wesley: Boston. 